\title{
Soil chemistry and microbial activity after a surface fire in a mixed temperate forest
}

\author{
Aliye Sepken Kaptanoğlu*1, Çağatay Tavşanoğlu², Oğuz Can Turgay ${ }^{3}$ \\ ${ }^{*}$ I Research Institute for Forest Soil and Ecology, Eskişehir, Turkey \\ ${ }^{2}$ Division of Ecology, Department of Biology, Hacettepe University, Beytepe 06800, Ankara, Turkey \\ ${ }^{3}$ Department of Soil Science and Plant Nutrition, Faculty of Agriculture, Ankara University, Dlşkapl, Ankara, \\ Turkey
}

Corresponding author: asepken@gmail.com

\begin{abstract}
Fire-affected soils have recently received more attention in soil science because some of the atmospheric $\mathrm{CO}_{2}$ emissions have directly been driven from soils during fires and climate change has increased fire frequency in many ecosystems of Earth. However, low-intensity surface fires and their effects on soil properties have been relatively less studied in comparison to moderate to high-intensity crown fires. In this study, the effect of a surface fire on the chemical and biological properties of soil with a thick organic layer was investigated in a mixed forest stand dominated by Castanea sativa, Fagus orientalis and Pinus nigra ssp. pallasiana in Bursa Province, Turkey. Soil samples were taken from burned and unburned (control) sites in three periods: December 2011, July 2012, and November 2013. Samples were analyzed to determine some chemical and biological properties in the soil. We tested the effect of fire and period on each variable by two-way ANOVA analysis. The results indicated that $\mathrm{Nt}$ and $\mathrm{OM}$ were not affected by fire, while $\mathrm{C} / \mathrm{N}$ ratio decreased. The difference between the periods was significant as regards $\mathrm{OM}$ and acid phosphatase enzyme activity. Fire resulted in a significant increase in soil $\mathrm{pH}, \mathrm{Ca}, \mathrm{Mg}$ and no significant change in $\mathrm{P}_{2} \mathrm{O}_{5}$. Although we found that surface fires limited the effect on soil properties, we concluded that there might be positive interactions between increased available nutrients in the soil and the burning of soil with relatively low severity. Prescribed fire can be proposed as a management tool to mitigate fire risks and short-time enrichment of available soil nutrients in these ecosystems.
\end{abstract}

Key words: C / N ratio, enzyme activities, forest, soil nutrients, and surface fire.

\section{Inroduction}

Soil holds vast reserves of carbon, which is two times more than the one held by the atmosphere, and provides food and fresh water security besides hosting biodiversity; therefore, it deserves much greater attention as the biggest environmental matter from the perspective of both climate change and human health (Mol and Keesstra 2012, Keesstra et al. 2016.) The effects of fire on soil are substantially caused by changes in nutrient amounts and cycles (Giardina et al. 2000, Knoepp et al. 2004). Temperate forest soils usually have low nutrient availability while the most limiting nutrient is Nitrogen (N) (Knoepp et al. 2004). Maintenance of plant growth depends on the internal cycling of nutrients in native forests (Perala and Alban 1982, Cole 1995). Due to the consumption and/or 
alteration of forest floor and woody fuels through prescribed burning or wildfire, both the quantity of nutrient-containing materials and the patterns of nutrient release change, and this process may indirectly affect soil nutrients (Knoepp et al. 2004). The release of available nutrients through the combustion of organic matter may be a significant natural source of plant growth (Kara and Bolat 2009). In fact, the decomposition rates on forest-floor may increase after burning, releasing $\mathrm{NH}_{4}{ }^{+}$ and other nutrients (Schoch and Binkley 1986, Khanna et al. 1994, Raison et al. 1990, Boydak et al. 1996). Decreasing decomposition rates due to the limited available organic matter after fire may eliminate this response in time (Raison et al. 1990). Since burning alters the nutrient status of soil; some other components of burning such as ash and debris nutrient content and quantity, nutrient loss with ash, amount of non-plant available nutrients' conversion into mineral forms due to thermal transformation, microbial biomass and activity (Giardina et al. 2000) (i.e. microbial enzyme activity, $\mathrm{C}$ and $\mathrm{N}$ mineralization rates) depend on nutrient status and they also deteriorate because of fire.

Many studies have been conducted on the effects of wildfire or prescribed fire on the physical and chemical (Eron 1977, Eron and Gürbüzer 1988, Neyişçi 1989, Neyişçi et al. 2002, Kantarc1 et al. 1986, Kutiel and Shaviv 1992, Boydak et al. 1996, Esquilin et al. 2008, Gürlevik et al. 2009, Tavşanoğlu and Gürkan 2010, Y1ldız et al. 2010) and biological (Akburak et al. 2017, Acea and Carballas 1996, Hernandez 1997, Villar et al. 2004, Kara and Bolat 2009) properties of soil in coniferous forests of Mediterranean and temperate zones, where crown fire regimes are dominant. Many ecosystems that are not exposed to frequent crown fires such as tropical and temperate broadleaved rainforests were also studied to explore the effects of fire on soil properties (Turgay et al. 2002, Barreiro et al. 2015). However, relatively less attention has been given to post-fire changes in soil's physical, chemical and microbial properties in mixed temperate forests where surface fire regimes prevail (see Knoepp et al. 2004, Swallow 2009). There is a lack of information especially about the changes in enzyme activity as an early and sensitive indicator (Taşkın anda Kizilkaya, 2006) and its relation with nutrient mineralization in the soil after burning of the forest floor following surface fires.

Temperate deciduous forests are among the most threatened ecosystems on Earth. Fire is one of the major disturbances affecting forests of temperate zone (Frelich 2002), whereas high-intensity crown fire is rare in these ecosystems (Matlack 2013). Therefore, fire return intervals are more than 800 years for crown fires, while decreasing as short as 21 years for surface fires (Brown et al. 1999).

The aim of this study was to assess the effects of surface fire on the chemical and biological properties of soil in a mixed temperate forest. Due to the low-intensity of surface fires in temperate forest ecosystems (Matlack 2013), we hypothesized that fire had a little effect on soil properties in these forests and, if any, post-fire regeneration would occur in a very short time. To test these hypotheses, we collected and analyzed soil samples for two years after fire in a burned mixed deciduous-coniferous forest in the northwest of Turkey, and we determined the changes in the chemical and biological properties of the soils.

\section{Materials and methods}

\subsection{Study area}

The study was conducted in a mixed broadleaved-coniferous forest in Uludağ, Bursa, northwest Turkey $\left(40^{\circ} 09^{\prime} 27^{\prime \prime} \mathrm{N}, 29^{\circ} 10^{\prime} 01^{\prime \prime} \mathrm{E}, 630-870 \mathrm{~m}\right)$. 


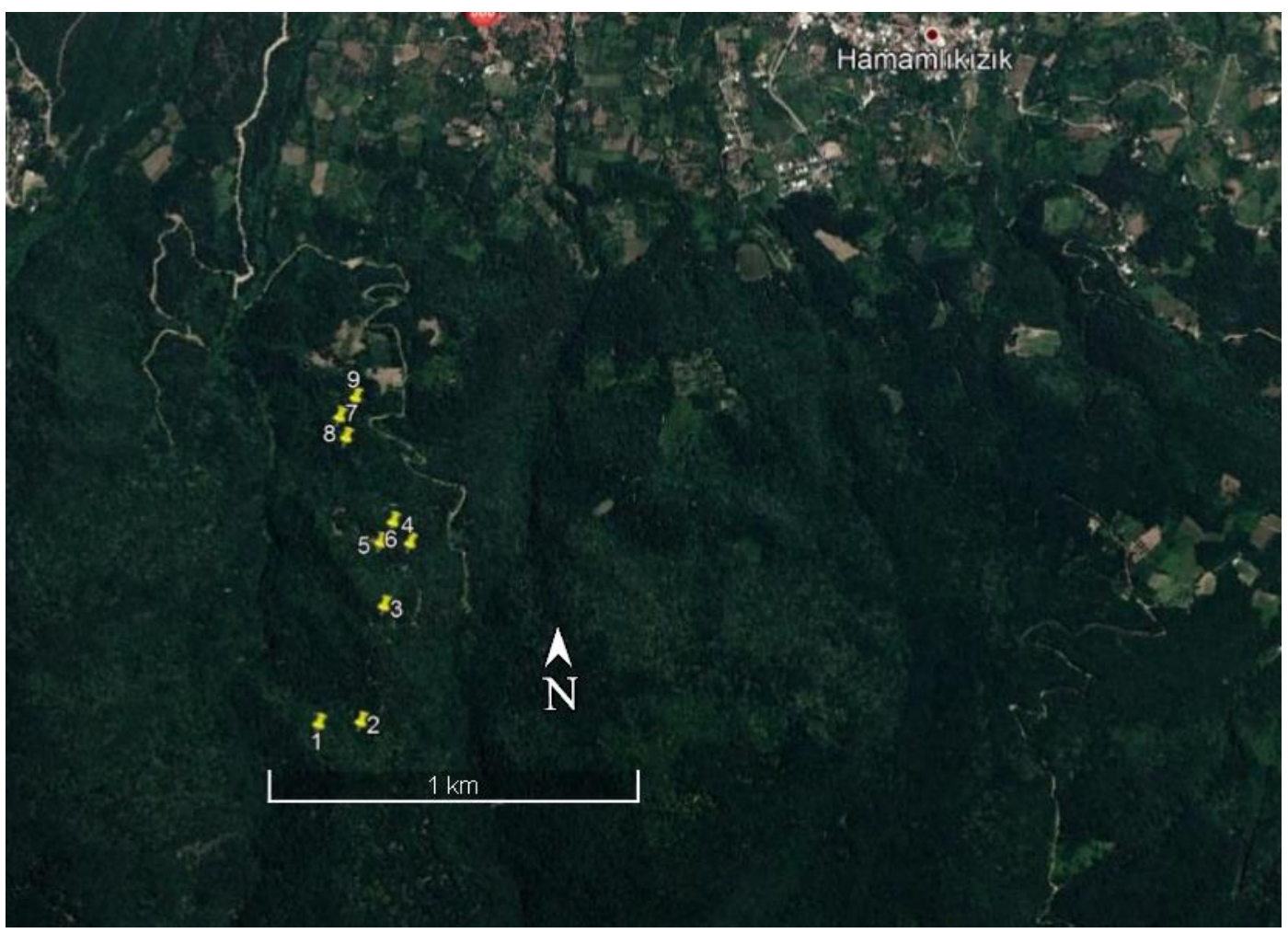

Figure 1. The location of the study area.

The dominant trees of the forests in the study area were Castanea sativa (sweet chestnut), Fagus orientalis (oriental beech) and Pinus nigra ssp. pallasiana (Anatolian black pine). About 78 ha forest area was burnt by a low-severity surface fire in December 2011. The study area is located on non-calcareous volcanic substrates and the soil texture consists of $70 \%$ sand, $12 \%$ silt, and $18 \%$ clay. The climate is sub-Mediterranean with 3-months dry period.

\subsection{Soil sampling}

The field studies were conducted in the burned and unburned sites of the study area to collect soil samples. The first sampling was conducted just one week after the fire (in December 2011) to assess the immediate effect of fire on soil properties. The second and the third samplings were performed seven months (in July 2012) and two years (November 2013) following the fire, respectively.

In each field study period, a total of 54 soil samples were taken from the surface distributed evenly to three replicate plots of 1 ha in size during the abovementioned periods. Sampling depth was determined as $0-15 \mathrm{~cm}$ and $15-30 \mathrm{~cm}$ considering the change in the soil surface roughness and the thickness of the organic layer. Three soil sampling points were determined randomly through a transect line in each plot. A group of soil samples were sieved ( $2 \mathrm{~mm}$ mesh) and stored at $4^{\circ} \mathrm{C}$ for soil biological analysis.

\subsection{Soil analysis}

Soil $\mathrm{pH}$ was determined in a $1: 5$ (v / v) soil/water solution (TS ISO 10390 2013). Soil electrical conductivity (EC) was determined in a $1: 5$ (m/ v) soil/water solution (TS ISO 11265 1996). Total organic carbon (Corg) content was measured by Walkley-Black (TS 8336 1990) and, organic matter by multiplying Corg with 1.72 . Total carbonate $\left(\mathrm{CaCO}_{3}\right)$ was determined by volumetric 
method (TS 8335 ISO 10693 1996). Available phosphorus $\left(\mathrm{P}_{2} \mathrm{O}_{5}\right)$ was determined according to the method of Bray-Kurtz (TS 8338 1990), and available K was determined by flamephotometer in $\mathrm{NH}_{4} \mathrm{OAc}$ extract according to the method described by Turkish Standard TS 8341 (1990). Ca and $\mathrm{Mg}$ were also extracted with $\mathrm{NH}_{4} \mathrm{OAc}$ and determined by atomic absorption spectrometer (Kacar 2009). Total N (Nt) content was determined by Kjeldahl digestion with the Kjeltec Auto 1030 Analyzer (Tecator 1987), and water content was determined gravimetrically after the soil was oven-dried for $24 \mathrm{~h}$ at $105^{\circ} \mathrm{C}$ (TS ISO 11465 1997). Acid phosphatase and $\beta$-D glucosidase activities were determined using $1.5 \mathrm{~g}$ of soil on a field-moist basis according to Dick and Tabatabai (1992).

\subsection{Statistical analysis}

Two-way analysis of variance (ANOVA) was conducted for the significance level of differences between the burned and unburned sites and between the periods as regards soil properties. Kolmogorov-Smirnov and Levene tests were applied to test the normality and homogeneity of variances, respectively. Data were $1 / \sqrt{ }$ transformed when they were not distributed normally. When parametric conditions were not met after the transformation, non-parametric Kruskal-Wallis test was performed. Associations between the soil parameters were determined by Pearson correlation analysis. All statistical analyses were conducted by using SPSS (version 21) (Özdamar 2004).

\section{Results}

Soil $\mathrm{pH}$ significantly increased in the burned sites immediately (from 5.2 to 5.6), and seemed not to change (5.0 and 5.5, respectively) $(\mathrm{F}=10.2, \mathrm{P}=0.003)$ in seven months after the fire. However, the difference disappeared (5.2 and 5.3, respectively) and the $\mathrm{pH}$ level in the burned site was the same with that of the unburned site in two years (Figure 2a).

The change in EC after the fire was statistically not prominent $(\mathrm{F}=1.04, \mathrm{P}>0.05)$ but the variation in this parameter was significant between the periods $(\mathrm{F}=4.98, \mathrm{P}=0.011)$. However, a week later after the fire, there was a significant increase in EC in the burned soil (Figure 2b).

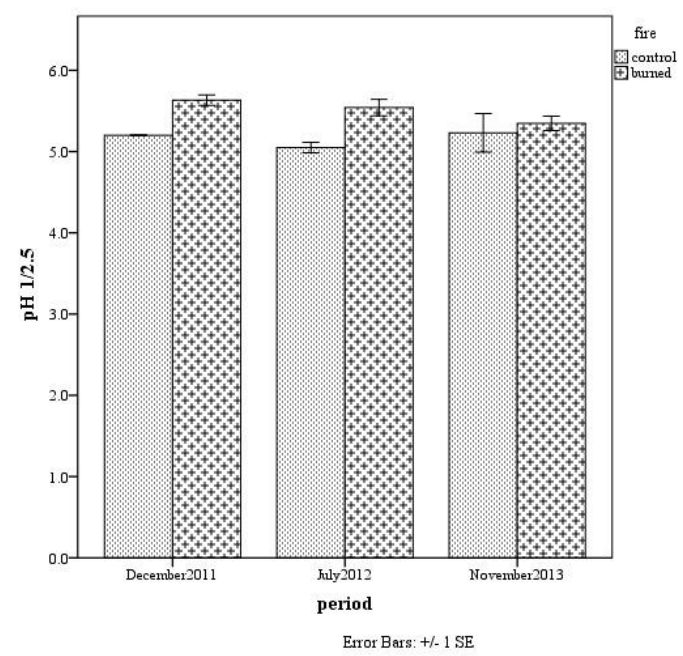

(a)

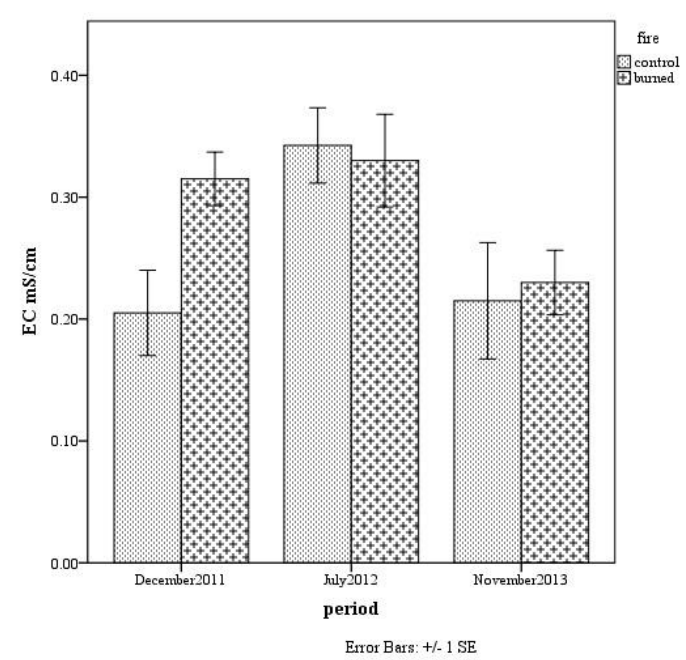

(b)

Figure 2. Soil pH (a) and EC (b) levels in the burned and unburned (control) soils after fire. 
No signficant difference was observed in organic matter content $(\mathrm{OM})$ between the control and burned plots $(\mathrm{F}=0.01, \mathrm{P}>0.05)$ but it was significantly different between the periods (Figure 3a, $\mathrm{F}$ $=5.9, \mathrm{P}=0.005)$. Although there was an insignificant increase in total nitrogen $(\mathrm{Nt})$ amount immediately after fire $(\mathrm{F}=2.8, \mathrm{P}>0.0 .05)$, the variation in $\mathrm{Nt}$ amounts was consistent with $\mathrm{OM}$ change in time (Figure $3 \mathrm{a}$ and $\mathrm{b}, \mathrm{F}=4.2, \mathrm{P}=0.022$ ).

$\mathrm{C} / \mathrm{N}$ ratio decreased significantly in all burned areas $(\mathrm{F}=6.33, \mathrm{P}=0.02)$ but the differences between the periods were insignificant (Figure $3 \mathrm{c}, \mathrm{F}=1.57, \mathrm{P}>0.05$ ). The difference in ratios between the control (26.24) and burned soils (19.71) went on in time with a decreasing trend. Two years later, they were 20.83 and 14.95 in the control and burned areas, respectively.

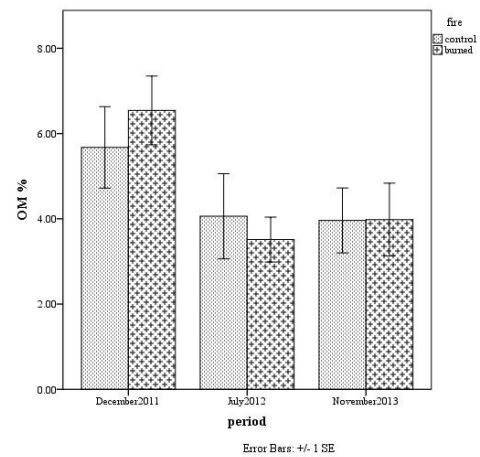

(a)

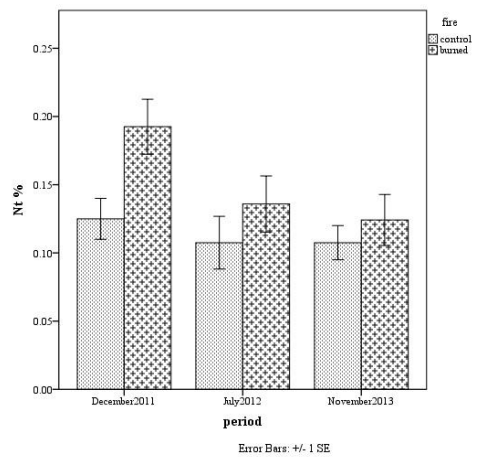

(b)

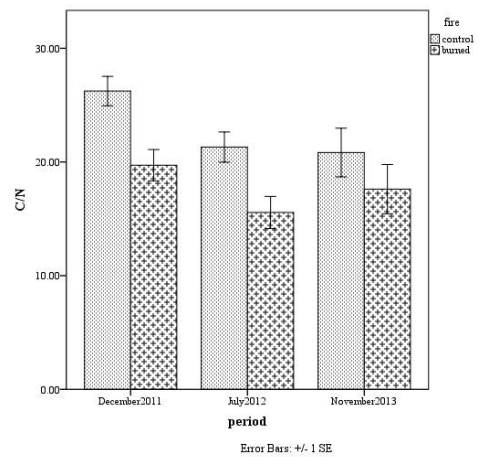

(c)

Figure 3. Soil OM (a), Nt (b) levels and C/N (c) in the burned and unburned (control) soils after fire.

No difference was observed in enzyme activities ( $\beta$-D glucosidase and acid phosphatase) due to fire $(\mathrm{F}=0.67, \mathrm{P}>0.05)$. However, the period effect on both of them was significant $(\mathrm{F}=6.12, \mathrm{P}=$ $0.005)$. The highest amount of acid phosphatase was in the last period $\left(0.28 \mathrm{mg} \mathrm{pNP} \mathrm{h}^{-1} \mathrm{~g}^{-1}\right)$, while the minimum amount was found in the first period $\left(0.15 \mathrm{mg} \mathrm{pNP} \mathrm{h}^{-1} \mathrm{~g}^{-1}\right)$. $\beta$-D glucosidase activity was compatible with acid phosphatase (Figure 4a, b).

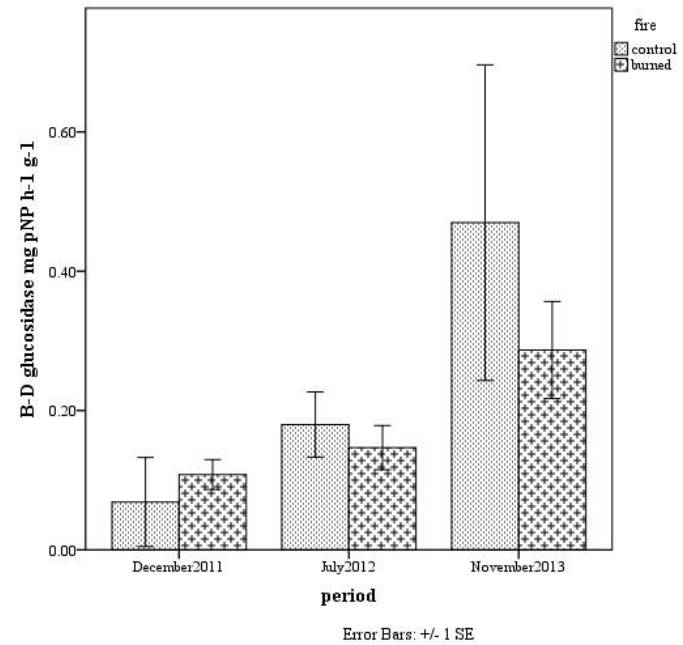

(a)

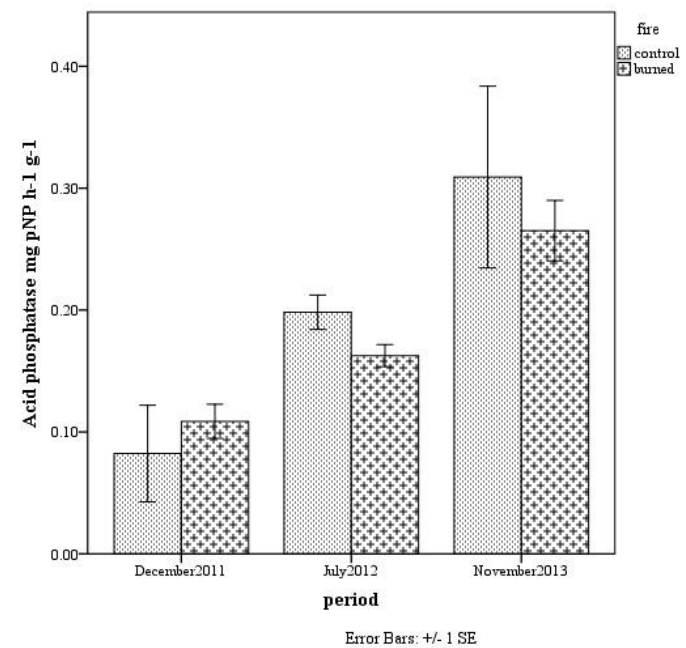

(b)

Figure 4. (a), (b) Soil enzyme activities in the burned and unburned (control) soils after fire. 
Fire effect on $\mathrm{Ca}(\mathrm{F}=5.13, \mathrm{P}=0.029)$ and $\mathrm{Mg}(\mathrm{F}=16.94, \mathrm{P}<0.001)$ was found to be significant. These nutrients both increased after burning (Figure 5a, b). The mean value of Ca was $840.4 \mathrm{ppm}$ and $1296.5 \mathrm{ppm}$, while $\mathrm{Mg}$ was $103.1 \mathrm{ppm}$ and $196.8 \mathrm{ppm}$, respectively, in the control and burned soils.

$\mathrm{K}$ amounts in the soil were not affected by either the fire $(\mathrm{F}=0.72, \mathrm{P}>0.05)$ or the period $(\mathrm{F}=$ $1.22, \mathrm{P}>0.05$ ) (Figure 5c,). There was a significant difference only in $\mathrm{Na}$ amounts between the periods $(\mathrm{F}=4139.1, \mathrm{P}<0.001)$. It was $96.25 \mathrm{ppm}$ in July 2012. In the first and the last periods, which were in autumn, $\mathrm{Na}$ amounts were found to be 3.7 and 5.7, respectively (Figure 5d).

There was an insignificant increase in available phosphorus amounts after fire, which was found to be $20.08 \mathrm{ppm}$ in the burned soils and $9.5 \mathrm{ppm}$ in the control soils in the first period (a week later after fire) (Figure 5e, $\mathrm{F}=0,69, \mathrm{P}>0.05$ ), while they were $8.13 \mathrm{ppm}$ and $6.73 \mathrm{ppm}$ in the last period (two years after fire).

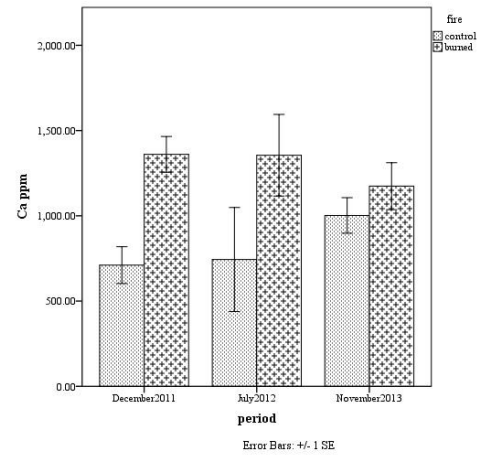

(a)

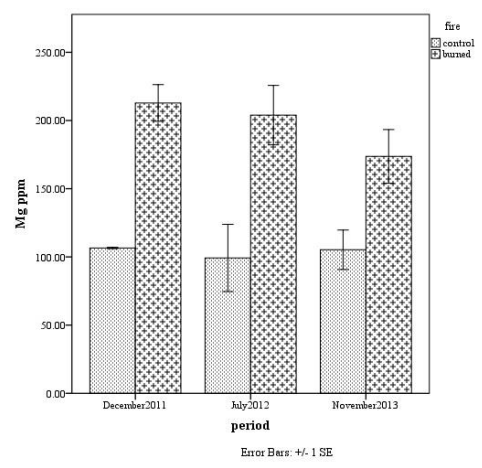

(b)

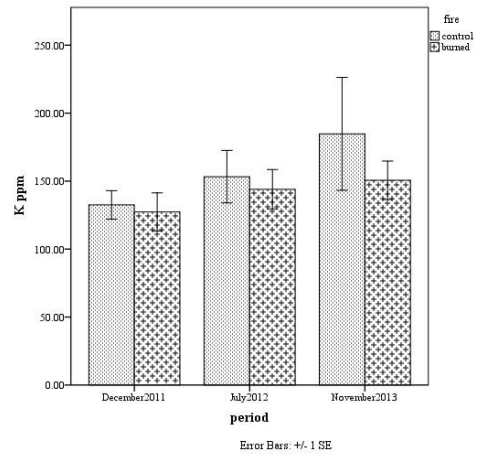

(c)

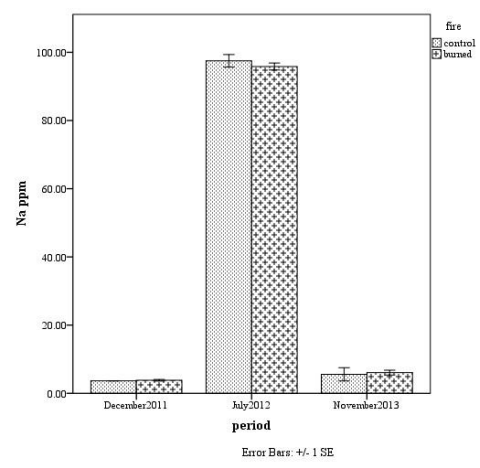

(d)

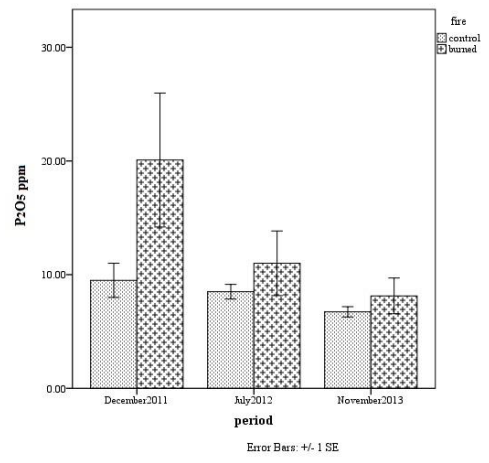

(e)

Figure 5. Soil $\mathrm{Ca}(\mathrm{a}), \mathrm{Mg}(\mathrm{b}), \mathrm{K}(\mathrm{c}), \mathrm{Na}(\mathrm{d})$ and $\mathrm{P}_{2} \mathrm{O}_{5}(\mathrm{e})$ in the burned and unburned soils after fire.

According to the correlation analysis (Table 1), there were positive linear correlations among $\mathrm{pH}$, $\mathrm{Nt}, \mathrm{P}_{2} \mathrm{O}_{5}, \mathrm{EC}, \mathrm{Ca}, \mathrm{Mg}$, whereas there was a negative relationship between $\mathrm{pH}$ and acid phosphatase enzyme activity. OM was correlated with $\mathrm{Nt}, \mathrm{C} / \mathrm{N}, \mathrm{P}_{2} \mathrm{O}_{5}, \mathrm{EC}, \mathrm{Ca}, \mathrm{Mg}$ and $\mathrm{K}$, although there was no relation between $\mathrm{Nt}$ and $\mathrm{C} / \mathrm{N}$ ratio. $\beta$-D glucosidase was correlated with acid phosphatase and $\mathrm{K}$. 
According to the correlation analysis (Table 1), there were positive linear correlations among $\mathrm{pH}$, $\mathrm{Nt}, \mathrm{P}_{2} \mathrm{O}_{5}, \mathrm{EC}, \mathrm{Ca}, \mathrm{Mg}$, whereas there was a negative relationship between $\mathrm{pH}$ and acid phosphatase enzyme activity. $\mathrm{OM}$ was correlated with $\mathrm{Nt}, \mathrm{C} / \mathrm{N}, \mathrm{P}_{2} \mathrm{O}_{5}, \mathrm{EC}, \mathrm{Ca}, \mathrm{Mg}$ and $\mathrm{K}$, although there was no relation between $\mathrm{Nt}$ and $\mathrm{C} / \mathrm{N}$ ratio. $\beta$-D glucosidase was correlated with acid phosphatase and $\mathrm{K}$.

Table 1. Pearson correlation coefficients (r) among measured variables in the study area. Asterisks refer to the level of significance; $*, \mathrm{P}<0.05 ; * *, \mathrm{P}<0.01$.

\begin{tabular}{|c|c|c|c|c|c|c|c|c|c|c|c|c|}
\hline & $\mathrm{pH}$ & OM & $\mathrm{Nt}$ & $\mathrm{C} / \mathrm{N}$ & $\mathrm{P}_{2} \mathrm{O}_{5}$ & $\mathrm{EC}$ & $\beta$-D Glucosidase & Acid Phosphatase & $\mathrm{Ca}$ & $\mathrm{Mg}$ & K & $\mathrm{Na}$ \\
\hline $\mathrm{pH}$ & 1 & .279 & $.527^{* *}$ & -.280 & $.424^{* *}$ & $.489^{* *}$ & -.253 & $-.317^{*}$ & $.595^{* *}$ & $.681^{* *}$ & -.078 & -.036 \\
\hline $\mathrm{OM}$ & & 1 & $.837^{* * *}$ & $.584^{* *}$ & $.577^{* *}$ & $.404^{* *}$ & .130 & -.188 & $.580^{* *}$ & $.382^{* *}$ & $.478^{* *}$ & -.262 \\
\hline $\mathrm{Nt}$ & & & 1 & .087 & $.725^{* *}$ & $.555^{* *}$ & .076 & -.269 & $.812^{* *}$ & $.701^{* *}$ & $.363^{*}$ & -.140 \\
\hline $\mathrm{C} / \mathrm{N}$ & & & & 1 & .031 & -.043 & .138 & .102 & -.075 & $-.386^{* *}$ & $.387^{* *}$ & -.195 \\
\hline $\mathrm{P}_{2} \mathrm{O}_{5}$ & & & & & 1 & $.382^{* *}$ & -.079 & -.261 & $.570^{* *}$ & $.461^{* * *}$ & .263 & -.095 \\
\hline $\mathrm{EC}$ & & & & & & 1 & .101 & -.174 & $.524^{* * *}$ & $.566^{* *}$ & .067 & $.327^{*}$ \\
\hline Acid Phosphatase & & & & & & & & 1 & -.019 & -.268 & .284 & -.091 \\
\hline $\mathrm{Ca}$ & & & & & & & & & 1 & $.734^{* *}$ & $.368^{*}$ & .024 \\
\hline $\mathrm{Mg}$ & & & & & & & & & & 1 & -.018 & .011 \\
\hline $\mathrm{K}$ & & & & & & & & & & & 1 & .037 \\
\hline
\end{tabular}

\section{Discussion}

Soil $\mathrm{pH}$ increases immediately after fire in most cases, declining to prefire levels in several months, years, or decades (Fisher and Binkley 2000). In this study, a prominent increase in soil $\mathrm{pH}$ might be related to $\mathrm{Ca}$ and $\mathrm{Mg}$ increase with fire due to the release of nutrients caused by the combustion of organic matter. The thick ash layer on the burned area was likely the most important source of these nutrients (Pereira P. 2012).

The availability of nutrients is influenced directly by geochemical factors and indirectly by microbial activity (Fisher and Binkley 2000). Positive correlations were found between $\mathrm{pH}$ and $\mathrm{Nt}$, $\mathrm{P}_{2} \mathrm{O}_{5}, \mathrm{Ca}$, and $\mathrm{Mg}$ (Table). Previous studies found highly significant positive correlations between pH and exchangeable Ca and Mg (Finzi et al. 1998, Quilchano and Maranon 2002).

Many studies reported that organic matter content of the soil decreased after fire (Eron 1977, Eron and Gürbüzer 1988, Neyişçi, 1989, Boydak et al., 1996, Certini, 2005, Neff et al. 2005, Tavşanoğlu and Gürkan 2010). On the other hand, the natural or artificial reintroduction of vegetation called secondary ecological succession, which has high net primary productivity, may lead to the recovery of soil organic matter in burned areas in a short time (Certini 2005). Soil organic carbon increase after fire may stem from the incorporation of unburned residues in mineral soil, the transformation of fresh organic materials to more recalcitrant forms, and the increase of $\mathrm{N}$-fixer species in the burned areas (Johnson and Curtis 2001). There was no significant increase in organic matter amount after fire though it was significant in terms of the period. Our results showed that the second and the third periods were not very different from each other while the difference between the first and the last two periods was considerable in terms of soil organic matter content. The immediate increase in $\mathrm{OC}$ after burning might be due to the formation of charcoal depending on incomplete combustion of organic matter (Kaptanoğlu Berber 2014). The insignificant difference between the last two periods probably derived from leaching of charcoal and recovery of the forest floor after a low-severity surface fire. 
The difference between the burned and unburned areas seemed insignificant in terms of Nt. However, fire resulted in relatively higher Nt amounts in the first period. It has been found that fire increases the nitrogen amounts (Boydak et al. 1996, Altun et al. 2004, Esquilin et al. 2008, Kara and Bolat 2008, Y1ldiz et al. 2010), which may be due to increased biological nitrogen fixation after fire (Kutiel et al. 1987, Kara and Bolat 2009).

Contrary to $\mathrm{OM}$ and $\mathrm{Nt}, \mathrm{C} / \mathrm{N}$ ratio was affected significantly by fire $(\mathrm{P}=0.017)$. After burning, $\mathrm{C}$ / $\mathrm{N}$ ratio was observed to decrease (Figure 3c). This result might depend on insignificant decrease in organic carbon content and is the evidence of the increased nitrogen mineralization after fire (Tecimen 2011, White 1986, Çepel 1975). Kantarc1 (2000) reported that decomposition was very low when $\mathrm{C} / \mathrm{N}$ ratio was greater than $30, \mathrm{C} / \mathrm{N}$ values ranging from 15 to 25 and values lower than 15 represented ongoing decomposition and very fast mineralization, respectively. Therefore, mineralization accelerated from lower values to higher values after surface fire.

Although increases in $\mathrm{P}_{2} \mathrm{O}_{5}$ amounts in burned soils were reported (Kutiel and Shaviv 1992, Boydak et al. 1996, Esquilin et al. 2008, Y1ldız et al. 2010), no significant differences between the burned and unburned soils as regards available phosphorus could be observed, which was confirmed in a study conducted in Pinus douglasiana Martínez-dominated forest stands in centralwestern Mexico 8 years, 28 years, and 60 years following a high-severity fire (Quintero-Gradilla et al. 2015). However, an immediate increase was observed after fire in burned areas in the first period, which diminished to the same levels in the unburned areas in last two periods. Increasing spatial variability in ash with time as a result of water erosion (Pereira et al. 2012) and/or overland flow (Dorta Almenar et al. 2015) could cause a decrease in $\mathrm{P}_{2} \mathrm{O}_{5}$.

EC values increased insignificantly after fire, but the difference between the periods was significant. Similar values were found in the first and second periods. Heating of soil with fire in the first period and under summer conditions in the second period might result in relatively warmer soils. The release of cations might be stimulated by the decomposition at rising temperatures. EC (saturated-extract electrical conductivity) values increased and decreased with exchangeable $\mathrm{Ca}$, exchangeable $\mathrm{Mg}$, and cation exchange capacity (McBride et al. 1990). A positive correlation was found between $\mathrm{EC}$ and $\mathrm{Ca}, \mathrm{Mg}$, and $\mathrm{Na}$ was in this study (Table). It was reported that cations like Ca, K, and Mg increased after fire (Khanna et al. 1994, Kutuel and Naveh 1987, Giardina et al. 2000, Knoepp et al. 2004).

Enzyme activities are influenced negatively by fire in most of the cases (Hernandez et al., 1997; Barreiro et al., 2015). Although there was no significant variation in $\beta$-D glucosidase and acid phosphatase activity after burning in this study, the period effect was significant. An increase in enzyme activities was observed depending on the period. It might stem from seasonal differences between November and July in the first year and climate changes year by year. The impact of fire on biological properties of soil depends strictly on soil moisture (Certini, 2005). The temperatures reached with fire might suppress the enzymes in a week following the fire and in later periods; little rainfall might result in low enzyme activity. It was reported that temperature and water potential of soil together may be better predictors of phosphatase activity than either one alone (Krämer and Green, 2000).

Acid phosphatase is released from plant roots although alkaline phosphatase is excreted by soil microorganisms (Okur et al. 2009, Krämer and Green, 2000) and affected by soil pH directly (Bilen, 2010). This enzyme activity reached a peak in the last period two years after the surface 
fire. It might be caused by root system development during the secondary vegetation over this period. Periodical variation in phosphatase activity might be related to $\mathrm{P}_{2} \mathrm{O}_{5}$ variation as well; phosphatase activity increased when $\mathrm{P}_{2} \mathrm{O}_{5}$ amount decreased in soil (Figure $3 \mathrm{~b}$ and $4 \mathrm{e}$ ). Although fire did not likely result in high level of $\mathrm{P}_{2} \mathrm{O}_{5}$ in the soil, it might prevent microbial excretion of phosphatase (Clarholm, 1993). In fact, an insignificant but negative correlation was observed between these parameters.

Although periods might likely cause some changes, the results in this mixed forest soil demonstrated that there was no considerable change after surface fires. However, increases in some nutrients such as $\mathrm{Ca}$ and $\mathrm{Mg}$ were observed in addition to decreasing $\mathrm{C} / \mathrm{N}$ ratio back to optimum levels in terms of mineralization. These changes may provide more higher amount and availability of nutrients for the new vegetation. We found a significant increase in soil $\mathrm{pH}$ as a consequence of a fire in the first period, which continued in the second period. A shift in $\mathrm{pH}$ levels back to its prefire condition could be observed in this study similar to the report of Trabaud (1983) and Durán et al. (2008). However, it seemed that even in the case of low-intensity surface fire, more than two years were needed to observe such a return in soil $\mathrm{Ca}, \mathrm{Mg}$ level, and $\mathrm{C} / \mathrm{N}$ ratio.

This study draws attention to the importance of fire severity on forest soils and is aimed to improve our knowledge on fire-affected soils in the ecosystems susceptible to surface fire. We concluded that surface fire effect on soil properties was limited. Soil properties did not considerably change after fire in the area except some exchangeable cations like $\mathrm{Ca}$ and $\mathrm{Mg}$. Management intervention to the burned forest floor after low-severity surface fires is not recommended. Furthermore, considering the advantages of natural regeneration of dominant tree species thanks to the enrichment of available nutrients or reduction of fire risk by limiting fuel accumulation, prescribed fires can be effectively used without any damage to soil in these ecosystems as a management tool.

\section{Acknowledgements}

We thank Regional Forest Directorate of Bursa for logistical support and Research Institute for Forest Soil and Ecology in Eskişehir for the soil chemical, physical and biological analyses, as well as Dr. Münevver Arslan for her assistance during the field work and Dr. Aydın Çömez for his valuable comments.

\section{References}

Acea, M.J., Carballas, T. (1996). Changes in physiological groups of microorganisms in soil following wildfire. FEMS Microbiology Ecology, 20, 33-39.

Akburak, S., Son, Y., Makineci, E., Çakır, M. (2017). Impacts of low-intensity prescribed fire on microbial and chemical properties in a Quercus frainetto forest. Journal of Forestry Research, 29, 687-696.

Altun, L., Bilgili, E., Sağlam, B., Küçük, Ö., Yılmaz, M., Tüfekçioglu, A. (2004). Soil organic matter, soil $\mathrm{pH}$ and soil nutritient dynamics in forest stands after fire. In: Proceedings of the International Soil Congress (ISC) on Natural Resource Management for Sustainable Development, Erzurum.

Aşkın, T., Kızılkaya, R. (2006). Assessing spatial variability of soil enzyme activities in pasture topsoils using geostatistics. European Journal of Soil Biology 42, 230-237.

Barreiro, A., Lombao, A., Martín, A., Carballas, T., Fonturbel, M.T., Vega, J.A., Fernández, C., Díaz-Raviña, M. (2015). Short-term effects of a wildfire on soil properties in Fragas do Eume Natural Park (Galicia, NW Spain), Flamma 6, 61-64. 
Bilen, S. (2010). Effect of cement dust pollution on microbial properties and enzyme activities in cultivated and no-till soils. African Journal of Microbiological Research, 4 (22), 2418-2425.

Boydak, M., Eler, Ü., Pehlivan, N. (1996). The effects of prescribed fire and some other foctors on succeed in regeneration of Antalya-Elmalı region cedrus. Technical Report, 2. Southwest Anotolia Forest Research Institute Publications, Antalya.

Brown, P.M., Kaufmann, M.R., Sheppard, W.D (1999). Long-term landscape patterns of fire events in a montane ponderosa pine forest of Central Colorado. Landsc Ecol, 14: 513-532.

Certini, G. (2005). Effects of fire on properties of forest soils: a review. Oecologia, 143:1-10.

Clarholm, M. (1993). Microbial biomass P, labile P, and acid phosphatase activity in the humus layer of a spruce forest, after repeated additions of fertilizer. Biology and Fertility of Soils, 8, 128-133.

Cole, D. (1995). Soil nutrient supply in natural and managed forests. Plant and Soil, 168, 43-53.

Çepel, N. (1975). Orman Yangınlarının Mikroklima ve Toprak Özellikleri Üzerine Yaptığı Etkiler (The effects of forest fires on microclimate and soil properties). İstanbul Üniversitesi. Orman Fakültesi Dergisi (Journal of Faculty of Forestry), 1, 71-93.

Dick, W.A., Tabatabai, M.A. (1992). Significance and Potential uses of soil enzymes. In: Meeting, F.B. (Ed.), Soil microbial ecology, applications in agricultural and environmental management, Marcel Dekker, New York: pp. 95-125.

Dorta Almenar, I., Navarro Rivero, F.J., Arbelo, C.D., Rodríguez, A., and Notario del Pino, J., (2015). The temporal distribution o water-soluble nutrients from high mountain soils following within legume scrubland o Tenerife, Canary Islands, Spain. Catena, 135, 393-400.

Durán, J., Rodríguez, A, Fernández-Palacios, J.M., Gallardo, A. (2008). Changes in soil N and P availability in a Pinus canariensis fire chronosequence. Forest Ecology and Management, 256: 384-387.

Eron, Z. (1977). Heating effects on forest soil physical properties and subsequent seedling growth. PhD, University of Montana, USA.

Eron, Z. ve Gürbüzer, E. (1988). The relationships between changes in soil properties and generation growing of red pine with the wildfire in Marmaris, 1979. Technical Report. Forest Research Institute, Ankara.

Esquilin, A.E.J., Stromberger, M.E., Shepperd, W.D. (2008). Soil scarification and wildfire interactions and effects on microbial communities and carbon. Soil Science and Society of America Journal, 72, 111-118.

Finzi, A.C., Canham, C.D., Breemen, N.V. (1998). Canopy tree-soil interactions within temperate forests: species effects on $\mathrm{pH}$ and cations. Ecological Applications, 8, 447-454.

Fisher, R., Binkley, D. (2000). Ecology and Management of Forest Soils, John Wiley \& Sons Inc. USA, pp. 241-261.

Frelich, L.E. (2002). Forest dynamics and disturbance regimes: Studies from temperate evergreen-decidious forests. Cambridge University Press, New York.

Giardina, C.P., Sanford, Jr.R.L., Dockersmith, I.C., Jaramillo, V.J. (2000). The effects of slash burning on ecosystem nutrients during the land preparation phase of shifting cultivation. Plant and Soil, 220, 247-260.

Gürlevik, N., Özkan, K., Gülcü, S. (2009). Effects of prescribed burning and mechanical site preparation on soil properties in a kermes oak field in Isparta region. Turkish Journal of Forestry, A (1), 24-37. 
Hernandez, T., Garcia, C., Reinhardt, I. (1997). Short-term effect of wildfire on the chemical, biochemical and microbiological properties of Mediterranean pine forest soil. Biology and Fertility of Soils, 25, 109-116.

Kantarcı, M.D., Parlakdağ, S., Pehlivan, N. (1986). Sedir Ormanlarının gençleştirilmesinde yangın kültürünün kullanımı ve ekolojik yorumu. Journal of the Faculty of Forestry, 36, 22-43.

Kantarc1, M.D. (2000). Toprak İlmi, İstanbul Üniversitesi Orman Fakültesi Yayınları, İstanbul.

Kara, Ö., Bolat, I. (2009). Short-term effects of wildfire on microbial biomass and abundance in black pine plantation soils in Turkey. Ecological Indicators, 9, 1151-1155.

Keesstra, S.D., Bourna, J., Wallinga, J., Tittonell, P., Smith, P., Cerdá, A., Montanarella, L., Quinton, J.N., Pachepsky, Y., van der Putten, W.H., Bardgett, R.D., Moolenear, S., Mol, G., Jansen, B., Fresco, L.O. (2016). The significance of soils and soil science towards realization of the United Nations Sustainable Development Goals, Soil, 2, 111-128.

Khanna, P.K., Raison, R.J., Falkiner, R.A. (1994). Chemical properties of ash derived from Eucalyptus litter and its effects on forest soils. Forest Ecology and Management, 66, 107-125.

Knoepp, J.D., Vose, J.M., Swank, W.T. (2004). Long-term soil responses to site preparation burning in the southern appalachians. Forest Science, 50, 540-550.

Kutiel, P., Naveh, Z. (1987). Soil properties beneath Pinus halepensis and Quercus calliprinos Trees on burned and unburned mixed forest on Mt. Carmel, Israel. Forest Ecology and Management, 20, 11-24.

Krämer, S., Green, D.M. (2000). Acid and alkaline phosphatase dynamics and their relationship to soil microclimate in a semiarid woodland. Soil Biology and Biochemistry, 32, 179-188.

Kutiel, P., Shaviv, A. (1992). Effects of soil type, plant composition and leaching on soil Nutrients following a simulated forest fire. Forest Ecology and Management, 53, 329-343.

Mc Bride, R.A., Shrive, S.C., Gordon, A.M. (1990). Estimating forest soil quality from terrain measurements of apparent electrical conductivity. American Society of Agronomy, 54, 290-293.

Matlack, G.R. (2013). Reassessment of the use of fire as a management tool in deciduous forests of eastern North America. Conservation Biology, 27, 916-926.

Mol, G. and Keesstra, S.D. (2012). Soil science in a changing World. Cur Opin Environ Sustainability, 4, 473-477.

Neff, J.C., Harden, J.W., Gleixener, G. (2005). Fire effects on soil organic matter content, composition, and nutrients in boreal interior Alaska. Canadian Journal of Forest Research, 35, 2178-2187.

Neyişçi, T. (1989). Kızılçam orman ekosistemlerinde denetimli yakmanın toprak kimyasal özellikleri ve fidan gelişimi üzerine etkileri. Ormancılık Araştırma Enstitüsü Yayınları Teknik Bülten Serisi, Ankara.

Neyişçi, T., Şirin, G., Sarıbaşak, H. (2002). Batı Akdeniz Bölgesinde orman yangını tehlikesinin düşürülmesinde denetimli yakma tekniğinin uygulanma olanakları. Türkiye Ormancılar Derneği Yayını, 2, Ankara.

Okur, N., Altındişli, A., Çengel, M., Göçmez, S., Kayıkçıŏglu, H.H. (2009). Microbial biomass and enzyme activity in vineyard soils under organic and conventional farming systems. Turkish Journal of Agricultural Forestry, 33, 413-423.

Özdamar, K. (2004). Paket Programlar ile İstatistiksel Veri Analizi. Kaan Yayınevi, Eskişehir. 
Perala, D.A., Alban, D.H. (1982). Rates of forest floor decomposition and nutrient turnover in aspen, pine, and spruce stands on two soils. USDA For. Serv., North Central Forest Exp. Sta., St. Paul, MN., USA.

Pereira, P., Cerda, A., Ubeda, X., Mataix-Solera, J., Martin, D., Jordan, A., Burguet, M. (2012). Effects of fire on ash thickness in a Lithuanian grassland and short-term spatio-temporal changes. Solid Earth Discussions, 4, 1545-1584.

Quilchano, C., Marañón, T. (2002). Dehydrogenase activity in Mediterranean forest soils. Biological Fertility of Soil, 35, 102-107.

Quintero-Gradilla, S.D., García-Oliva, F., Cuevas-Guzmán, R., Jardel-Peláez, E.J., Martínez-Yrizar, A. (2015). Soil Carbon and Nutrient Recovery after high-severity Wildfire in Mexico. Fire Ecology, 11, 45-61.

Raison, R.J., Keith, H., Khanna, P.K. (1990). Effects of fire on the nutrient-supplying capacity of forest soils. Dyck WJ, and CA Mees (eds.), In Proceedings IEA/BE Workshop, Impact of Intensive Harvesting on Forest Site Productivity, Forest Research Institute, Rotorua, South Island, New Zealand, p. 39-54.

Schoch, P., Bınkley, D. (1986). Prescribed burning increased nitrogen availability in a mature loblolly pine stand. Forest Ecological Management, 14, 13-22.

Swallow, M., Quideau, S.A., MacKenzie, M.D., Kishcuk, B.E. (2009). Microbial community structure and function: The effect of sivicultural burning and topographic variability in northern Alberta. Soil Biology and Biochemistry, 41, 770-777.

Tavşanoğlu, Ç., Gürkan, B. (2010). Physical and chemical properties of the soils at burned and unburned Pinus brutia Ten. forest sites in the Marmaris region. Hacettepe Journal of Biology and Chemistry, 38: 7176.

Tecator (1987). Determination of Kjeldahl nitrogen content with the Kjeltec Auto 1030 Analyzer. Application Note, AN 30/87, Hönagäs, Sweden.

Tecimen, H.B. and Sevgi, O. (2011). Heating induced changes in mineral nitrogen and organic carbon in relation with temperature and time. Journal of Environmental. Biology, 32, 295-300.

Trabaud, L. (1983) The effects of different fire regimes on soil nutrient levels in Quercus coccifera garrigue. In: Kruger, F.J., Mitchell, D.T., Jarvis, J.U.M. (Eds). Mediterranean-type ecosystems: role of nutrients. Springer, Berlin Heidelberg New York, pp. 233-243.

TS 8335 ISO 10693 (1996). Toprak kalitesi -Karbonat Tayini - Volumertik Yöntem. Türk Standardları Enstitüsü (Turkish Standards Institution), Ankara.

TS 8336 (1990). Topraklar - Organik Madde Tayini. Türk Standardları Enstitüsü (Turkish Standards Institution), Ankara.

TS 8338 (1990). Topraklar - Fosfor Tayini - Modifiye Bray ve Krutz Yöntemi No 1 Türk Standardları Enstitüsü (Turkish Standards Institution), Ankara.

TS 8341 (1990). Topraklar - Potasyum Amonyum Asetat Yöntemi. Türk Standardları Enstitüsü (Turkish Standards Institution), Ankara.

TS ISO 10390 (2013). Toprak kalitesi - pH tayini. Türk Standardları Enstitüsü (Turkish Standards Institution), Ankara.

TS ISO 11265 (1996). Toprak kalitesi - Elektiriksel Öziletkenlik tayini. Türk Standardları Enstitüsü (Turkish Standards Institution), Ankara. 
TS ISO 11465 (1997). Toprak Kalitesi - Kütle Esasına Göre Kuru Madde ve Su Muhtevasının Tayini Gravimetrik Yöntem. Türk Standardları Enstitüsü (Turkish Standards Institution), Ankara.

Turgay, O.C., Lumbanraja, J., Yusnaini, S., Nonaka, M. (2002). Effect of land degradation on soil microbial biomass in a hilly area of south Sumatra, Indonesia. Soil Sci Plant Nut, 48, 769-774.

Villar, M.C., Petrikova, V., Diaz-Ravina, M., Carballas, T. (2004). Changes in soil microbial biomass and aggregate stability following burning and soil rehabilitation. Geoderma, 122, 73-82.

White, C.S., (1986). Effects of prescribed fire on rates of decomposition and nitrogen mineralization in a ponderosapine ecosystem. Biology and Fertility of Soils, 2: 87-95.

Yildız, O., Esen, D., Sargınc1, M. and Toprak, B. (2010). Effects of forest fire on soil nutrients in Turkish pine (Pinus brutia, Ten) Ecosystems. Journal of Environmental Biology, 31, 11-13.

Submitted: 08.08.2018

Accepted: 13.11.2018 